\title{
Physical Discomfort Faced by the School Children while Carrying School Backpack
}

\author{
Kanchan Shilla*, Komal and Sudesh Gandhi \\ Department of Family Resource Management, I. C. College of Home Sciences, CCSHAU, \\ Hisar - 125004, Haryana, India \\ *Corresponding author
}

K e y w o r d s
$\begin{aligned} & \text { School children, } \\ & \text { Musculoskeletal } \\ & \text { symptoms, School } \\ & \text { backpacks, Discomfort }\end{aligned}$
Article Info
$\begin{aligned} & \text { Accepted: } \\ & \text { 25 May } 2018 \\ & \text { Available Online: } \\ & \text { 10 June } 2018\end{aligned}$

The greatest concerns to school students are physical, cognitive, emotional and social development. The school children's major health issue in the India is the use of overweight school backpacks. Backpacks used by school children can lead to poor posture and they might develop back pain and strain their shoulders and neck. Heavy backpacks carrying by school students can cause irreversible physical harms because school student's spine is in the stage of development. So, present study was undertaken with the objective of to assess the physical discomfort faced by the school children while carrying school backpack. The body discomfort i.e. shoulder pain, lower back pain, upper back pain, neck pain, lower arm pain, upper arm pain and pain in legs have been seen in school children due to very weighty school backpacks. Lower back, legs and shoulders were the most affected body parts of respondents. It was also found that the walking, standing and stepping up and down from stairs activities with carrying school backpack required the corrective measures. Preventive and educational activities should be implemented to reduce the backpack load.

\section{Introduction}

School students at the age of 11-14 years with their consistent rate of growth and development have greatest concerns to physical, cognitive, emotional and social development. The use of school backpack filled with educational and other related accessories (i.e. books, stationary, tiffin, water bottle etc.) is one of the forms of manual load carriage used by school children. Weight of the backpack strongly related to the incidence of shoulder, neck, back, and extremities complaints in school students. School backpacks used by school students can lead to poor body posture and they might develop pain and strain in lower back, upper back, shoulders and neck. Overweight school backpacks are responsible for a considerable quantity of back pain in school children which may be due to the changes in lumbar disc height or curvature. School students may be at risk for musculoskeletal injuries especially lower back and upper back related injuries because they carry loads that are heavier in proportion to their body weight which may lead to compress backbone abnormally and musculoskeletal deformity in later life. School backpacks can be threatening to the wellbeing of school students when they are too heavy. Heavy backpacks carrying by school students can cause irreversible physical problems 
because school student's spine is in the critical stage of development. Carrying overweight backpacks may contribute adverse health effect on school children. So due to school backpack, high and rising occurrence of health problems in children is matter of concern.

So, present study was therefore taken up with the objective to assess the body discomfort due to school backpack in children while carrying school backpack.

\section{Materials and Methods}

For conducting the study two schools of Hisar city were randomly selected. Out of each selected school, ten school children were randomly selected. Thus the total constituted sample was 20 respondents. An interview schedule was developed and used for field survey.

Human body discomfort map and OWAS (OVAKO work posture analysis system) were used to assess the body discomfort due to school backpack in children while carrying school backpack. The data were tabulated and analysed by using the following statistical tools i.e. weighted mean score, frequency, percentages and rank.

\section{Results and Discussion}

\section{Physical parameters of respondents}

Table 1. Showed that half of the respondents were 14 years of age and minimum number of respondents (10 percent) were 12 years of age. It is revealed 45 percent of respondents belonged to height category of $145-155 \mathrm{cms}$ and maximum numbers of respondents $(65$ percent) fall into weight category of $30-40 \mathrm{Kg}$. George et al., (2015) also found out musculoskeletal discomfort due to back pack weight in school students aged between $10-$ 12 years attending 5 th- 7 th standard.

\section{BMI of respondents}

Table 2. revealed that 35 percent of respondents had BMI (Body Mass Index) in the range of 18.5-24.9 and 65 percent of respondents had BMI less than 18.5. Mean $\mathrm{BMI}$ of the respondents was $16.38( \pm 2.22)$.

\section{Mode of journey and distance travelled by the respondents}

Data in Table 3 revealed that average distance travelled by the respondents was $1 \mathrm{~km}$ and 87 meters (+0.84) on each day; and 35 percent of respondents covered this distance on foot followed by bicycle $(30$ percent of respondents), by auto (25 percent of respondents) and by bike (10 percent of respondents). Average travel time taken by the respondents with carrying school backpack was 29 minutes $( \pm 9.03)$ on each day. It indicates that generally school children had to travel longer distances with school backpack.

\section{Measurements of school bag}

It is revealed in Table 4 that 55 percent of respondents carry backpack on both shoulders and 45 percent of respondents carry backpack on one shoulder. It was also revealed in Table 4 that. Mean weight of school backpack was $7.30( \pm 1.43)$. Mean width, mean length and mean height of school backpack was $13.3( \pm$ 1.49), 30.8( \pm 3.66) and 31.4( \pm 3.54) respectively. Zakeri Y et al., (2016). Found out that non-standard backpack weight increases the prevalence of dropped shoulders, kyphosis and lordosis in school students that can put in danger the physical health of the school students. Similarly Daneshmandi et al., (2008) revealed in their study that school backpacks weight exceeding $10 \%$ of the body weight increases energy consumption, increases the neck and trunk forward lean, results in decreasing lung volumes and increased cardio-respiratory parameters. 
Table.1 Physical parameters of respondents

\begin{tabular}{|l|c|c|}
\hline \multicolumn{1}{|c|}{ Parameters } & Frequency & Percentage \\
\hline Age (in years) & & \\
\hline $\mathbf{1 2}$ & 2 & 10 \\
\hline $\mathbf{1 3}$ & 8 & 40 \\
\hline $\mathbf{1 4}$ & 10 & 50 \\
\hline Height(in cm) & 4 & 20 \\
\hline$<\mathbf{1 4 5}$ & 9 & 45 \\
\hline $\mathbf{1 4 5}-\mathbf{1 5 5}$ & 7 & 35 \\
\hline$>\mathbf{5 5}$ & & \\
\hline Weight(in Kg) & 2 & 10 \\
\hline$<\mathbf{3 0}$ & 13 & 65 \\
\hline $\mathbf{3 0 - 4 0}$ & 5 & 25 \\
\hline$>40$ & & \\
\hline
\end{tabular}

Table.2 Physical parameters of respondents

\begin{tabular}{|l|c|c|c|c|}
\hline $\begin{array}{c}\text { BMI Score } \\
\left(\mathrm{kg} / \mathrm{m}^{2}\right)\end{array}$ & Frequency & Percentage & Description & Mean $( \pm$ S.D. $)$ \\
\hline$<\mathbf{1 8 . 5}$ & 13 & 65 & Underweight & \\
\hline $\mathbf{1 8 . 5}-\mathbf{2 4 . 9}$ & 7 & 35 & Normal weight & $16.38( \pm 2.22)$ \\
\hline
\end{tabular}

*BMI was calculated by Quetlet's Index $=$ Weight $(\mathrm{kg}) /$ Height $^{2}(\mathrm{~m})$

Table.3 Mode of journey and distance travelled by the respondents

\begin{tabular}{|c|c|c|c|}
\hline Parameters & Frequency & Percentage & Mean $( \pm$ S.D. $)$ \\
\hline \multicolumn{4}{|l|}{ Distance travelled* (in Km) } \\
\hline$<1$ & 4 & 20 & \multirow{3}{*}{$1.87( \pm 0.84)$} \\
\hline $1-2$ & 9 & 45 & \\
\hline$>2$ & 7 & 35 & \\
\hline \multicolumn{4}{|l|}{ Mode of journey } \\
\hline On foot & 7 & 35 & \\
\hline By auto & 5 & 25 & \\
\hline Bycycle & 6 & 30 & \\
\hline Bike down & 2 & 10 & \\
\hline \multicolumn{4}{|l|}{ Travel time* (in minutes) } \\
\hline$<20$ & 3 & 15 & \multirow{3}{*}{$29( \pm 9.03)$} \\
\hline $20-30$ & 9 & 45 & \\
\hline$>\mathbf{3 0}$ & 8 & 40 & \\
\hline
\end{tabular}

* With school bag 
Table.4 Measurements of school bag

\begin{tabular}{|c|c|c|c|}
\hline Parameters & Frequency & Percentage & Mean $( \pm$ S.D. $)$ \\
\hline \multicolumn{4}{|l|}{ Type } \\
\hline Backpack (carry on both shoulders) & 9 & 45 & \\
\hline Shoulder bag (carry on one shoulder) & 11 & 55 & \\
\hline \multicolumn{4}{|l|}{ Weight (with accessories) (in Kg) } \\
\hline$<6$ & 3 & 15 & \multirow[b]{2}{*}{$7.30( \pm 1.43)$} \\
\hline $6-7$ & 7 & 35 & \\
\hline$>7$ & 10 & 50 & \\
\hline \multicolumn{4}{|l|}{ Size } \\
\hline \multicolumn{4}{|l|}{ Width (in cm) } \\
\hline$<12$ & 4 & 20 & \multirow[b]{2}{*}{$13.3( \pm 1.49)$} \\
\hline $12-15$ & 16 & 80 & \\
\hline \multicolumn{4}{|l|}{ Length (in cm) } \\
\hline$<30$ & 5 & 25 & \multirow[b]{2}{*}{$30.8( \pm 3.66)$} \\
\hline $30-35$ & 15 & 75 & \\
\hline \multicolumn{4}{|l|}{ Height (in cm) } \\
\hline$<30$ & 6 & 30 & \multirow{2}{*}{$31.4( \pm 3.54)$} \\
\hline $30-35$ & 14 & 70 & \\
\hline
\end{tabular}

Table.5 Analysis of Human Body Map Discomfort

\begin{tabular}{|l|l|c|c|}
\hline Sr. no. & Body part & WMS & Rank \\
\hline 1. & Neck & 2.5 & V \\
\hline 2. & Shoulder & 4.1 & I \\
\hline 3. & Upper arm & 3.6 & III \\
\hline 4. & Lower arm & 2.2 & VI \\
\hline 6. & Legs & 2.1 & VII \\
\hline 7. & Upper back & 3.5 & IV \\
\hline
\end{tabular}

Corlett and Bishop's scale (1976)

Table.6 OWAS analysis for different stages of school backpack carrying

\begin{tabular}{|c|c|c|c|c|c|c|}
\hline Stages & Back & Arms & Legs & Load & $\begin{array}{l}\text { Action } \\
\text { category }\end{array}$ & $\begin{array}{l}\text { Action } \\
\text { required }\end{array}$ \\
\hline Walking & $\begin{array}{l}2 \text { (Bent } \\
\text { forward) }\end{array}$ & $\begin{array}{l}1 \text { (both arms } \\
\text { are below } \\
\text { shoulder level) }\end{array}$ & $\begin{array}{l}7 \text { (walking or } \\
\text { moving) }\end{array}$ & $\begin{array}{l}1 \text { (no effort } \\
\text { or effort less } \\
\text { than } 10 \mathrm{~kg} \text {.) }\end{array}$ & 2 & $\begin{array}{l}\text { Corrective } \\
\text { measures in the } \\
\text { near future }\end{array}$ \\
\hline Standing & 2 (bent) & $\begin{array}{l}3 \text { (both arms } \\
\text { are below } \\
\text { shoulder level) }\end{array}$ & $\begin{array}{l}3 \text { (standing } \\
\text { with the } \\
\text { weight) }\end{array}$ & $\begin{array}{l}1 \text { (no effort } \\
\text { or effort less } \\
\text { than } 10 \mathrm{~kg} \text {.) }\end{array}$ & 3 & $\begin{array}{l}\text { Corrective } \\
\text { measures as } \\
\text { soon } \\
\text { possible }\end{array}$ \\
\hline $\begin{array}{l}\text { Stepping up } \\
\text { and down } \\
\text { from stairs }\end{array}$ & $\begin{array}{l}4 \text { (Bent } \\
\text { forward) }\end{array}$ & $\begin{array}{l}1 \text { (both arms } \\
\text { are below } \\
\text { shoulder level) }\end{array}$ & $\begin{array}{l}7 \text { (walking or } \\
\text { moving) }\end{array}$ & $\begin{array}{l}1 \\
\text { (less than } 10 \\
\mathrm{~kg} \text { ) }\end{array}$ & 2 & $\begin{array}{l}\text { Corrective } \\
\text { measures in the } \\
\text { near future }\end{array}$ \\
\hline
\end{tabular}




\section{Analysis of Human Body Map Discomfort}

Table 5. revealed that most of the respondents posed shoulder pain (WMS 4.1, rank I) followed by Lower back (MS 3.9, rank II), upper arm pain (MS 3.6, rank III), Upper back pain (MS 3.5, rank IV) and neck pain (MS 2.5, rank V). Pant et al., (2016). also found out that school children while carrying school backpacks faced high discomfort in neck, shoulder and back.

\section{OWAS analysis for different stages of school backpack carrying}

Composite score for different stages of school backpack carrying was determined by using OWAS (OVAKO work posture analysis system). The standing stage of the respondents with carrying school backpack was required corrective measures as soon as possible while walking with carrying school backpack and stepping up and down from stairs required corrective measures in the near future. Oviedo et al., (2012) also analysed in their study that the prevalence of school children carrying heavy backpacks is extremely high so preventive and educational activities should be implemented in 12-17 age group.

The heavy backpack load on the back has led to serious of physical problems like backache, neck pain, shoulder pain etc. School children faced problems in different body parts and high discomfort was found in shoulder and back. According to the OWAS sheet walking, standing and stepping up and down from stairs required the corrective measures as soon as possible. The musculoskeletal symptoms (i.e. shoulder pain, back pain, neck pain, lower arm pain and upper arm pain) in school children due to carrying heavy backpacks have been seen. Carrying overweight backpacks increases the risk of musculoskeletal discomfort in school children.

\section{References}

Corlett E N and Bishop R P (1976) A technique for assessing postural discomfort. Ergonomics 19: 175-82.

Daneshmandi H, Nia F R, Hosseini S H (2008). Effect of carrying school backpacks on cardio respiratory changes in adolescent students. Sports sciences for health. 4: 7-14

George D, Nayak S B, Shetty S (2015). Bag pack weight and Musculoskeletal discomfort among school children. Nursing and Midwifery Research Journal. Vol-11.

Oviedo P R, Ravina A R, Ríos M P, García B, Fernández D G, Alonso A F, Núñez I C, Pacios P G, Turiso J (2012). School children's backpacks, back pain and back pathologies. Arch Dis Child. 97: 730-732.

Pant K, Kaur H and Sidhu M (2016) Assessment of problems faced by school children while carrying school bags. International Journal of Scientific Research. 5:19-20.

\section{How to cite this article:}

Kanchan Shilla, Komal and Sudesh Gandhi. 2018. Physical Discomfort Faced by the School Children while Carrying School Backpack. Int.J.Curr.Microbiol.App.Sci. 7(06): 3437-3441. doi: https://doi.org/10.20546/ijcmas.2018.706.402 